\title{
THOMAS ADÈS AT 50: REPRESENTATIONS ON THE STAGE AND ON THE PAGE
}

\author{
Edward Venn
}

On the evidence of the last year alone, Thomas Adès's international profile, as well as his productivity, remains undiminished as he enters his sixth decade. In a concert on 6 March 2021 to mark his fiftieth birthday, he conducted Kirill Gerstein and the London Symphony Orchestra in a performance of his In Seven Days and Sibelius's Sixth Symphony. Because lockdown restrictions in response to Covid-19 were still in force, the celebratory nature of the concert was necessarily muted - given behind closed doors, the players distanced - and only later uploaded to YouTube. ${ }^{1}$

Nevertheless, and despite the difficulties of music-making in the pandemic, Adès's music has continued to be heard: Dawn, for orchestra, was premiered at the 2020 BBC Proms by Sir Simon Rattle and the London Symphony Orchestra; Inferno (2019) received its European premiere by the Accademia Nazionale di Santa Cecilia and Gianandrea Noseda; Shanty - Over the Sea (2020), for string orchestra, was premiered by the Australian Chamber Orchestra; ${ }^{2}$ and Gyökér (Root), for soprano and four percussionists, was included in Oliver Zeffman's Eight Songs from Isolation (2020), released as a film on Apple Music. In the same period, the New York Metropolitan Opera streamed their productions of Adès's The Tempest and The Exterminating Angel and the Royal Danish Opera their production of Powder Her Face. New recordings were released to critical acclaim: Adès's piano music played by Han Chen; his Totentanz, the Concerto for Piano and Orchestra, In Seven Days and other piano works with Kirill Gerstein, the Boston Symphony Orchestra and the Tanglewood Music Center Orchestra; and Adès's cycle of Beethoven symphonies with the Britten Sinfonia, coupled with works by Gerald Barry.

But for the pandemic there would have been even more. The most high-profile UK cancellations of Adès's music in the last 12 months were the premieres of the Angel Symphony (now The Exterminating Angel Symphony) by Mirga Gražinytè-Tyla and the City of Birmingham Symphony Orchestra, the Royal Opera House's performance (and simultaneous cinema broadcast) of the complete ballet Dante (of which Inferno was the opening part) and a season-long celebration of Adès at the Barbican. The programming of the Barbican season is revealing for how it would have portrayed the composer,

\footnotetext{
${ }^{1}$ The concert is available for viewing at https://youtu.be/PqNurqMnfdQ (accessed 22 April 2021).

2 The UK premiere of Shanty was given by Adès and the Britten Sinfonia in a concert in the Barbican, London, on 10 June 2021.
} 
most notably in the emphasis given to his stage works. The Luxury Suite from Powder Her Face was to open the season, the London premiere of the Angel Symphony would have represented The Exterminating Angel and a concert performance of The Tempest would have brought Adès's second opera to the UK for the first time since 2007. Dante would also have featured, performed by Gustavo Dudamel and the Los Angeles Philharmonic, and Shanty was to receive what would have been its world premiere during a residency at the Barbican by the Australian Chamber Orchestra. To mark Adès's fiftieth birthday itself, he would have conducted a concert that, doubtless with ironic intent, was to include his Totentanz (2013). ${ }^{3}$

What is striking about this rollcall is the prominence given to Adès's recent and brand-new music. It must have been especially hard for promoters and programmers, in an anniversary year, to resist indulging in a retrospective that wheeled out greatest hit after greatest hit. Perhaps the enduring presence of Adès's music in concert halls and recording studios over the last 30 years, seemingly immune from the waxings and wanings of critical fortune that have beset so many living composers, rendered such a retrospective superfluous: with but a few exceptions, his back catalogue has never really gone away.

Indeed, the multiple live renditions of Adès's music uploaded to YouTube attest to the appeal Adès holds for performers (and, by extension, audiences) around the world; ${ }^{4}$ it is remarkable to see the extent to which successive generations of musicians rise to, and then normalise, the technical and musical challenges that Adès sets them. (Philip Hensher, the librettist for Powder Her Face, has spoken in the past of the difficulties in the 1990s of casting the high soprano part of the Maid - without Valdine Anderson in the role he suggests the opera might not have happened; 20 years later, this is no longer the case. $^{5}$ )

Just as performances have proliferated, so too has the scholarship around Adès's music. In the wake of the early reception of Adès in the popular press, which gravitated to extremes of adulation or sneering, the commentary that sprung up around Adès at the turn of the millennium did much to locate the burgeoning field of Adès studies on a more secure critical footing. ${ }^{6}$ This was soon followed by detailed technical analyses of the music, encouraged, no doubt, by the close alignment of Adès's rhythmic and, especially, intervallic tendencies with the concerns of the music-theoretical community (especially in North America). ${ }^{7}$ In the last decade, there has been a profusion of

${ }^{3}$ This is the concert that was eventually replaced by Sibelius's Sixth Symphony and In Seven Days. In the light of the continuing catastrophe of the pandemic, there was little need for Totentanz's reminder of our collective mortality.

${ }^{4}$ Related to this are the large numbers of interviews with Adès that are available on YouTube

${ }^{5}$ Philip Hensher, in 'Philip Hensher and Meredith Oakes in Conversation with Paul Archbold', Be Not Afeard: Language, Music and Cultural Memory in the Operas of Thomas Adès, Senate House, University of London, 25 April 2017.

${ }^{6}$ Key texts here include Richard Taruskin, 'A Surrealist Composer Comes to the Rescue of Modernism', New York Times, 5 December 1999, reprinted with a postscript in The Danger of Music and Other Anti-Utopian Essays (Berkeley and Los Angeles: University of California Press, 2009), pp. 144-52; Arnold Whittall, 'James Dillon, Thomas Adès, and the Pleasures of Allusion', in Aspects of British Music of the 1990s, ed. Peter O' Hagan (Aldershot: Ashgate, 2003), pp. 3-27; and Christopher Fox, 'Tempestuous Times: The Recent Music of Thomas Adès', Musical Times, 145, no. 1888 (2004), pp. 41-56.

${ }^{7}$ For instance, see Aaron Travers, 'Interval Cycles, Their Permutations and Generative Properties in Thomas Adès's Asyla' (PhD dissertation, University of Rochester, 2004); John Roeder, 'Co-operating Continuities in the Music of Thomas Adès', Music Analysis, 
$\mathrm{PhD}$ theses, articles and book chapters devoted in part, or entirely, to Adès's music. Adès's increasing willingness to discuss his music, most notably in his collection of interviews with the broadcaster Tom Service, ${ }^{8}$ has done much to stimulate scholarly response, bringing with it questions and issues around critical distancing and objectivity. Though this locus of scholarly activity remains firmly in the Anglo-American sphere, the first monograph on the composer was published in French, ${ }^{10}$ and there remains a slow but steady stream of non-anglophone publications on Adès's music. To bring the story up to date, and to demonstrate the continued health of scholarship in this area, Adès's fiftieth birthday year marks the arrival of two book-length studies that survey his output up to, and including, The Exterminating Angel. ${ }^{11}$

The four articles brought together in this TEMPO symposium were conceived with Adès's anniversary year in mind. However, given that Adès's 'distinctive creative persona' is, paradoxically, characterised by 'an identity that is in constant flux, made of ambiguity and multiplicity, so that no single definition of the nature of that identity can suffice' (as Arnold Whittall succinctly puts it in his article), the challenge remains as to how one might celebrate, and critically reflect upon, his achievements. In the end, and in common with the performances of his music in the last 12 months (whether given or not), the symposium offers only so much by way of celebratory retrospective. Rather, the emphasis is firmly upon tracing certain features of Adès's art, highlighting continuities as well as divergences across his output and bringing some of his most recent music into consideration.

In 'Adès at 50: Precarious Poise', Arnold Whittall offers a virtuosic survey of some of the key aesthetic and technical preoccupations that animate Adès's music. Opening not with Adès, but with Stravinsky and Britten, Whittall signals the degree to which Adès's music engages productively, if sometimes combatively, in dialogue with traditions (plural, and not just musical). In contrast to Whittall's arial (and Ariel!) view, James Donaldson's 'Topics, Double Coding, and Form Functionality in Thomas Adès's Piano Quintet' provides a close reading of the technical and semantic properties of just three chords. Donaldson demonstrates that, even at this microscopic level, Adès achieves the same delicate balance between apparently irreconcilable aesthetic perspectives that Whittall demonstrates on the macrolevel. In 'Adès and Sonata Forms' I take up another aspect of Adès's engagement with tradition - form - and offer readings of all four of Adès's sonata-form movements to date (from the Chamber Symphony Op. 2 to the Concerto for Piano and Orchestra from 2018). These works suggest that Adès's use of 'textbook' formal

25, nos 1-2 (2006), pp. 121-54; and Philip Stoecker, 'Aligned Cycles in Thomas Adès's Piano Quintet', Music Analysis, 33, no. 1 (2014), pp. 32-64.

8 Thomas Adès and Tom Service, Thomas Adès: Full of Noises - Conversations with Tom Service (London: Faber and Faber, 2012).

9 See, for instance, the discussion of the performative nature of Adès's statements and my own response to them in Edward Venn, Thomas Adès: Asyla (Abingdon: Routledge, 2017), pp. xv-xvi. Christopher Wiley and Ian Pace's edited volume Research and Writing on Contemporary Art and Artists: Challenges, Practices, and Complexities (Palgrave Macmillan, 2020) offers a more detailed introduction to the challenges of maintaining 'a respectable level of critical distance' (p. 4) when writing about contemporary artists.

10 Hélène Cao, Thomas Adès le voyageur: Devenir compositeur, être musicien (Paris: MF Éditions, 2007).

11 Drew Massey, Thomas Adès in Five Essays (New York: Oxford University Press, 2021) and Edward Venn and Philip Stoecker (eds), Thomas Adès Studies (Cambridge: Cambridge University Press, 2021). 
models are more complex than has been acknowledged, not least in the interplay between syntactical groupings and tonal plot. Finally, in 'A New Dawn? Thomas Adès and the Case of Musical Simplicity', Richard Powell demonstrates how the surprisingly direct nature of the materials of Dawn challenges the conventional wisdom that has accrued around Adès and complexity. Nevertheless, through his articulation of the affinities between the repetitions within Dawn and practices elsewhere in Adès's output, Powell deftly demonstrates the ways in which Adès's creative identity, to return to Whittall's description, is one of both 'constant flux' yet coherent enough to be 'distinctive'. All told, the portrait of the composer at 50 that emerges from our symposium is inevitably partial and incomplete, but also dynamic, poised between the accomplishments of Adès's past and anticipation of the works that will follow in the future. 